\title{
17 Reinterpreting nature
}

\author{
A brief environmental history of trilateral conservation in \\ the Wadden Sea region
}

Anna-Katharina Wöbse and Hans-Peter Ziemek

\begin{abstract}
In the early twentieth century, the Wadden Sea coast witnessed the arrival of new stakeholders: nature lovers and ornithologists started to be concerned about the status and vulnerability of the regional avifauna. This was just the start of a new social movement that was to become one of the driving forces behind the debate of how to frame the Wadden Sea - as a region to be developed or as the "last European wilderness"? Now, at the beginning of the twenty-first century and considering the joint World Heritage Site, it seems clear who 'won' the debate: over the last four decades, issues surrounding the unique natural values of the Wadden Sea have gained widespread public and political awareness. This paper focuses on a more recent chapter in the long history of relations between humans and the Wadden Sea by revisiting sites and actors of environmental history along the coast. It explores the emergence of trilateral cooperation in order to explain the multi-layered texture of the environmental discourse in the 'era of ecology'.
\end{abstract}

Keywords: environmental history, civil society, trilateral diplomacy, political awareness, environmental discourse

\section{Introduction}

A long divide seems to run through today's popular conception of the Wadden Sea region. The dikes separate the dry from the wet land, safety from danger, cultivated landscapes from wilderness, culture from nature. However, the Wadden Sea as a prototype of an area in a constant state of

Egberts, Linde \& Schroor, Meindert (eds.), Waddenland Outstanding: The History, Landscape and Cultural Heritage of the Wadden Sea Region. Amsterdam: Amsterdam University Press, 2018 DOI: 10.5117/9789462986602/CH17 
flux offers a rich field for rethinking the concepts not only of land and water but also of the transnational sphere that the specific environment as such constitutes. With that constant transition in mind, one can easily detect a certain hybridity and ambivalence in the many human relations with the Wadden Sea and Waddenland, which deserve a more interdisciplinary and multidimensional approach (Gillis 2011). Environmental history offers such a diverse approach to analyse the many entanglements of space, culture, ecology and politics of the region. It studies the human interaction with the natural world over time and challenges the national frame at both the subnational and supranational levels - the local and the global (Blackbourn 2011). This perspective might help us to understand the dynamics of the fundamental changes that have taken place in the region over the last $5^{0}$ years. One such fundamental change relates to the public perception of the Wadden Sea.

Today, hardly anyone would dare to challenge its spatial coherence, its European dimension, its global uniqueness, its ecological vulnerability and distinctiveness, its economic value or its transnational character. UNESCO acknowledged and emphasised its 'natural' entity when inscribing it on the World Natural Heritage List. The World Natural Heritage rhetoric seems to tell a simple and predictable story of the rise of ecological awareness and reason. However, when looking at this commonly cited rhetoric of natural heritage from a historical perspective, we find that it is only fairly recently that the narrative of the Wadden Sea received such 'green' attributions. For most of the twentieth century, it was instead perceived as a threatening, poor and neglected sphere fragmented by use and national demarcation (Reise 2013). Given today's image of the Wadden Sea as a transnational and somehow boundless space, it is illuminating to take a closer look at the process of changing the narrative. How did that conversion from a peripheral into a global sphere come about? In this paper, we focus on a recent chapter in the long history of relations between humans and the Wadden Sea by revisiting the sites and actors of the environmental discourse along the Wadden Sea coast. As there is no coherent historical account of the environmental 'globalisation' of the Wadden Sea yet, this paper seeks to outline some cornerstones of that process. For understanding the multi-layered texture of the environmental discourse in the 'era of ecology' (Radkau 2011) and the prevalence of today's ecological reading of the Wadden Sea, it is worth surveying the emergence of international cooperation and networking. 


\section{Changing perceptions of the Wadden Sea in the early twentieth century}

The term 'Wadden Sea' as such only emerged in the course of the nineteenth century, signifying the intertidal zone in the southeastern part of the North Sea. Perhaps the most interesting traveller to have described the area was Johann Georg Kohl, a geographer and writer from Bremen. In 1846, he published an account on a journey along the coast in which he described the Wadden World as reaching from Kap Blavaands Huk to Holland. Kohl talked about a common sphere characterised by the same natural features (Kohl 1846). Within the scientific community, we find that at the end of the nineteenth century the idea of the Wadden Sea as a distinct habitat began to evolve, with Karl Möbius thinking about the Wattenmeer as a habitat for oysters (Möbius 1877). In 1904, the Danish natural scientists Eugenius Warming and Carl Wesenberg-Lund wrote about the Wadden Sea (Vadehavet in Danish) as a distinctive ecological feature reaching from Skallingen to Texel. With the beginning of the twentieth century, the specific biological interest in the Wadden Sea area intensified. From then on, we find a growing number of specific and detailed studies on various issues like sedimentation, wadden (mudflat) production, wadden habitats like salt marshes and species like fish, cockles and mussels (Bietz 2004; Reise 2013). However, although there was a growing interest among professional scientists for the habitat, investigation and research was individualistic, nationally oriented, and not committed to protecting this particular landscape.

At around the turn of the twentieth century, new stakeholders entered the Wadden stage: nature lovers, friends of the sea birds and ornithologists. They started promoting the Wadden Sea as an important stopover on the intercontinental flyways of migratory birds. According to the preservationists, this transit sphere was under acute threat. Modern transportation brought tourists and hunters to the islands. A market for selling seabird eggs to city dwellers emerged.

Accordingly, the first generation of nature protection activists, who witnessed the decline of their feathered friends, started to fight for reserves (Weigold 1924). They would buy or lease uninhabited islands and other 'places of beauty' along the coast, put a fence around it, and send in wardens. One such site of early activism was the now-defunct Danish Hallig Jordsand near the island of Sylt. In 1907, a small group of engaged citizens of Hamburg leased the Jordsand (which was German territory at the time) to protect emblematic sea birds, especially terns and oystercatchers. This project was built on sand and was threatened as such by constant erosion. Thus, 
the Verein Jordsand looked for new places to protect, deciding to lease the Hallig Norderoog (Ziemek \& Wöbse 2016: 68-69). Over the next years, bird societies and governmental agencies established small reserves along the Wadden Sea coast. The threatened birds became the most prominent symbols of the disrupted relationship between humans and nature. As the migrating birds - resting for feeding on their way up north or staying for breeding - ignored any boundaries, the international dimension of the Wadden Sea triggered a certain internationalism among birders and preservationists. Nonetheless, theirs was a piecemeal approach that helped to safeguard individual locations but did not change much about the growing exploitation of coastal resources in terms of tourism, hunting and egg consumption.

\section{Re-evaluating the wetlands}

After the end of the Second World War, the pressure on the environment of the Wadden Sea grew steadily. The dynamics of the postwar economy and development schemes changed the environment along the shores of the North Sea dramatically (Lotze, Reise \& Worm 2005). New infrastructure, large-scale mechanisation in agriculture, massive industrial pollution of the air and water, and the societal shift towards a consumer society started to significantly affect the Wadden Sea region. Moreover, new types of uses and interests arose: the coastal wetlands were increasingly claimed by the fast-growing market of mass tourism, exploration and drilling for oil and gas, and national and allied air forces in search of spacious military training grounds.

This was not a phenomenon occurring only in the Wadden Sea - it was a development witnessed all over Europe and even worldwide. Wetlands as such came under extreme pressure when the era of postwar reconstruction kicked in. The extent of human intervention such as drainage increased significantly in the second half of the twentieth century - today some two-thirds of the European wetlands that existed 100 years ago have been lost (European Commission 1995). Swamps, bogs and estuaries constituted obstacles to economic and social progress, and few appreciated their ecological and aesthetic features. The post-war reconstruction ethos valued the expansion of arable land, economic growth and the control over the wetlands and the sea more than the preservation of natural landscapes and habitats. When the International Union for the Protection of Nature (IUCN) was founded in Fontainebleau in 1948, the delegates made a field trip to the 
swamps of the Camargue in southern France. This ornithological hotspot, home to more than 400 bird species, was probably the most iconic wetland in Europe but was highly threatened by drainage and land reclamation. The small network of international conservationists challenged the commonly held notion that wetlands were landscapes of the past, waiting only to be eliminated. And so, fittingly, the Camargue was selected as the location for the first conference, in 1962, focusing on the protection of marshes, deltas, mudflattidal-flat areas, swamps and estuaries. This 'MAR conference' (MAR evoking various terms like the English marsh, the German Marsch, the French marais and the Spanish marisma) was decisive for the global future of the Wadden Sea. The delegates set out to change the bad image of allegedly useless wetlands and suggested a completely new framing, stressing instead their specific productivity and unique value and promoting them as 'liquid assets'. This marked a fundamental change in wetland policies (Matthews 1993). The wetland alliance was intended to foster economic and political appreciation for this hitherto marginalised habitat. Instead of simply fencing reserves off, the conference recommended a system of 'wise use'. The activists involved in the emerging network of wetland conservation set out to internationalise the threat to water-bound landscapes. Coordinating and synchronising the efforts for protection seemed necessary, as the extinction of wetlands was an urgent issue, and human resources were scarce: 'Things are moving so fast and habitat is being destroyed so rapidly that there is simply not enough available manpower to obstruct, tackle or modify each and every drainage project that comes to our notice.' (Scott 1963: 38). Almost defiantly, the ecologists coined the slogan: 'Wetlands are never wastelands!' (IUCN 1965: 16).

However, in the era of general euphoria over spatial planning and technical modernisation, few voices raised concerns over the future of the Wadden Sea area as a habitat. But in 1966, when another conference on wetlands was convened in the Dutch town of Noordwijk, the networkers played the moral and political card by drawing the attention of the Netherlands government 'to the exceptional biological value of the Waddenzee.' The conference stressed that 'the Netherlands has a great responsibility to the countries of northern and western Europe' (resolutions reprinted in Wolff 1976). The tidal flats were pushed into the spotlight of environmental diplomacy by a small but very efficient network of international activists and ecologists who identified the Wadden Sea with a worldwide web of wetlands. In 1965 the interdisciplinary International Wadden Sea Working Group, led by the young Dutch biologist Wim Wolff, began to coordinate the research. This turned into an epicentre for the development of a trilateral science 
community for the protection of the natural Wadden Sea, and along with this, the Wadden Sea as a whole entered the scientific agenda of the three bordering states (Van der Windt 1992).

Scientists found their allies in civil society. In the mid-196os, local interest organisations began to team up with international conservation groups in an attempt to shift perceptions of this peculiar land and seascape. After a long history of taming the sea as well as massive security measures, the tides literally started turning as Dutch society began exhibiting a growing resistance to large-scale building schemes. Nature lovers and biologists rallied behind the plan: in October 1965, they founded the Wadden Sea Society, which was to become something of a blueprint for NGO action and strategies along the coast. A new era in human-Wadden Sea relations began. There were young urbanites who wanted to have a say in how to handle that coastline and its hinterlands. They discovered a seemingly long-forgotten Dutch wilderness (Westerman 2009; Deen 2014; Freriks 2015). The new generation presented their endeavours as something young, vital and modern. Meanwhile, the World Wildlife Fund suggested the Wadden Sea as a test case on which to base the settlement of environmental conflicts. It was listed among other prestigious wetlands, and this fostered its unique and yet universal transnational character and status (Wöbse 2015).

During the 196os, social movements influenced the political democratic system in Western Europe. Engaged citizens — among them environmentalists - voiced their ambition to participate in planning processes and development schemes. All the talk about the limits of growth, spaceship earth, just one planet, etc. was an indication of the fundamental doubt being expressed about former concepts of resource management and the exploitation of nature.

In 1962, Rachel Carson published her groundbreaking book Silent Spring on the far-reaching effects of the massive use of the insecticide DDT in the US and worldwide. Such planetary boundlessness could be seen and felt in the Wadden Sea area in an almost brutal and frightening way: the industrial pollution of the sea reached a disturbing severity as early as the 196os. In 1965 , thousands of Sandwich terns were found dead or dying with tremors and convulsions on the Dutch island of Texel. And between 1955 and 1965, another breeding colony on the island of Griend declined from more than 20,000 pairs to about 1,000. A study by Dutch scientists discovered residues of a number of chlorinated hydrocarbon insecticides in terns and spoonbills. The residues of insecticides proved to be the highest near the mouth of the river Rhine and at locations stretching northeast from there. The contaminated water moved along the Dutch coast in a northeasterly direction and 
entered the Wadden Sea as well as German waters (Koeman et al. 1968). The visibility of the pollution sparked new environmental awareness. Pollutants coming in from the international waters of the Rhine, the Ems, the Weser and the Elbe carried an increasing amount of problematic substances, which then accumulated in the Wadden Sea (Erz 1972). Not only were migrating sea birds and the appealing seals symbols of the transnational character of the Wadden Sea's maritime sphere, but so were the pollutants and pollution. The visual narrative of the sea depicting wide horizons, white seagulls and unspoiled beaches was now being contrasted by illustrations of wastewater pipes, floating oil and yellowish foam.

Concurrently, Europe as a normative concept and potential political entity started to matter. In 1967, the European Council declared 1970 to be the year of nature protection (Wöbse 2016). In 1970, De Boschplaat, a nature reserve on the island of Terschelling, was awarded the European Diploma of Protected Areas. Such symbolic acts and honours reflected how environmentalism was slowly becoming the norm. The Dutch government was very proactive in lobbying for the first wetland convention that led to the Ramsar Convention, signed in 1971, the first international agreement dealing with a specific habitat type (Matthews 1993). Again, this did not necessarily lead to strict legal measures. However, the challenge of being part of the vanguard of ecological modernisation and fulfilling international requirements by listing national wetlands of international importance surely accelerated political acceptance. This was just one element in a much larger picture: ecology changed the perception of the natural world and challenged not only national and political demarcations but also economical concepts and programmes. Such shifts in perception correlated with political and societal changes. Boundaries as such started to blur.

\section{Wadden Sea International}

The many small steps and initiatives to reframe the Wadden Sea as a rich, diverse and unique habitat rather than a disadvantaged fringe gained political and institutional momentum. Meanwhile, the Dutch government, encouraged by the public campaigns, asked the IUCN to draft an 'International Convention on the Conservation of the Wadden Sea'. The Union suggested a system of demarcation, regulation and zoning. This draft was far-reaching. It suggested an area to be protected stretching from Den Helder to Blavands Huk, covering not only the shoreline, the islands and the open sea but also 10 kilometres inland of the coast. In 1974, the IUCN sent its 
proposal to the governments of the Netherlands, Germany and Denmark. Its supranational perspective met with reluctance beyond the Dutch border (Wolff-de Boom 1983: 152). The German government was even openly hostile. The foreign office rejected any such convention, as the ministry of defence and the ministry of economy refused to let any international NGO hamper their rights of national sovereignty. ${ }^{1}$ However, the idea was out there, and the political stakeholders were forced to somehow respond to the IUCN's trilateral concept, which carried the normative aura of an acknowledged international institution. Although the convention was never enacted, the draft did set standards for environmental diplomacy. Moreover, it kicked off the Trilateral Wadden Sea Cooperation and its secretariat (Enemark 2005). When governmental delegations met in The Hague for the first time in 1976 and Germany refused to join any international agreement, the Dutch delegation stated nonchalantly 'that some cooperation would be necessary anyway - public opinion would force politicians to do so.' ${ }^{2}$ And they were proven right.

The tremendous dynamics of relations between humans and the environment in the Wadden Sea region are handed down to us in a prestigious book published more than 40 years ago. In 1976, the Landelijke Vereniging tot Behoud van de Waddenzee, in cooperation with the Vereniging tot Behoud van Natuurmonumenten in Nederland, and orchestrated by the tireless Dutch activist Jan Abrahamse, published an impressive volume (in Dutch, Danish and German) presenting the trilateral Wadden Sea as an extraordinary, vulnerable and vast landscape. It listed the many vested interests in the area, from fisheries to the national militaries. Moreover, it collected aspects of the long cultural history and the latest scientific findings on the flora and fauna of the wetlands. The book was a manifestation of a new approach towards the Wadden Sea: activists and scientists from all three neighbouring states contributed to the volume and celebrated the ecological uniqueness and transboundary character. The twin messages of ecological entity and historical connectedness were masterfully illustrated, particularly with the use of high-quality aerial photography. The visual storyline focused on the boundlessness of the Wadden Sea region and featured the area more as shared than as national territory. Moreover,

1 Zwischenarchiv im Politischen Archiv des Auswärtigen Amtes 107854, 414/495.0o SB-2: Konvention zur Erhaltung der Wattenmeere, 1976, Vermerk über die Ressortbesprechung zum Entwurf eines Wattenmeer-Übereinkommens am 25.6.1976 im BML.

2 Zwischenarchiv im Politischen Archiv des Auswärtigen Amtes 107854, 414/495.00 SB-2: Konvention zur Erhaltung der Wattenmeere, 1976, Vermerk über die Ressortbesprechung zum Entwurf eines Wattenmeer-Übereinkommens am 25.6.1976 im BML. 
Figure 17.1 Book cover of Abrahamse et al., Waddenzee, 1977.

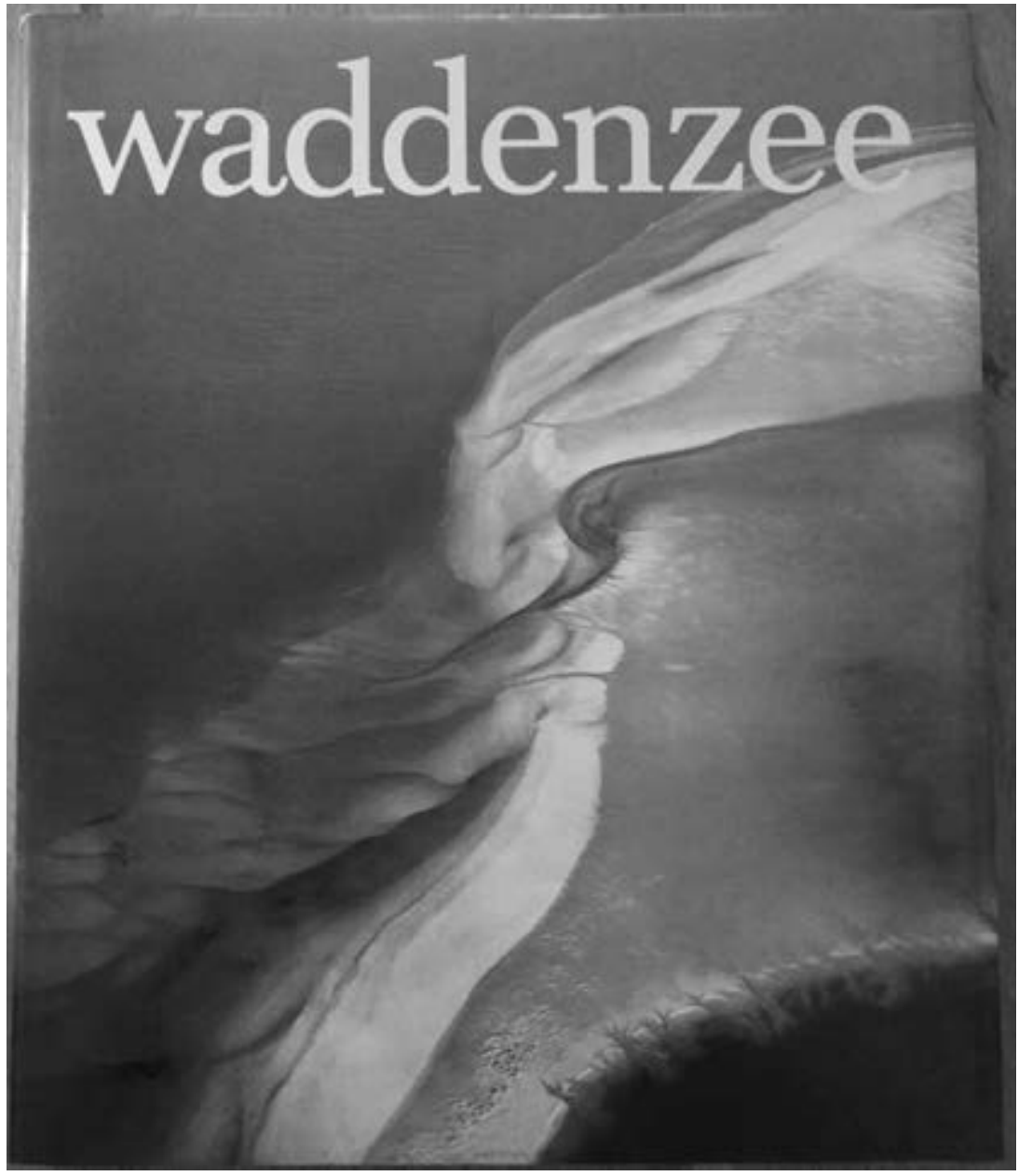

Photo by Herman Conens, Aerofoto Eelde, courtesy of Waddenvereniging

the widely distributed book, which saw several editions, anticipated the international trajectory that the political Wadden Sea discourse was about to take. At the very end of the account, the authors stated confidently that the Wadden Sea area was a 'natural space of importance reaching beyond Europe' (Landelijke Vereniging 1976: 349).

In Germany, for instance, new social movements teamed up with oldschool conservationists. German and Danish pro-Wadden Sea activism was influenced and supported by Dutch initiatives, especially the Dutch Wadden Society, which offered many blueprints for how to steer public protest 
and political attention (Wöbse 2015). Colourful campaigns and innovative lobbying drew the public eye to the ecological fragility of the Wadden Sea. The rise of the Green Party forced conservative politicians to rethink their ideas about economic modernisation of the coastal region and made national parks an interesting option for 'greening' their party programmes. The Wadden Sea was no longer a murky fringe area but a contested political arena. The concept of modernisation was now to be supplemented with environmental aspects. In 1978, the three nations pursued a common conservation policy; in 1982 a 'Joint Declaration on the Protection of the Wadden Sea' was signed in Copenhagen. It featured a common secretariat that was established in Wilhelmshaven (Germany) in 1987. The 1980s and 1990s saw massive investments in fundamental ecological research projects along the coast (Wolff 1983; Umweltbundesamt 2002). The Wadden served as a space of opportunity and provided a huge laboratory for the field studies of young ecologists. Due to the trilateral and even global dimension that the Wadden Sea had gained over the diplomatic negotiations, their local studies were now automatically part of transboundary research interests. A genuine environmental infrastructure emerged: new institutions, new national parks and reserves, and new monitoring programmes came into existence all along the coast. The shift in mindset made a significant spatial difference. Development was at least tamed or hedged in.

\section{Conclusion}

As Karsten Reise has suggested, the shift in attitude towards the Wadden Sea was the result of various dynamic developments (Reise 2013:56-59). The new environmental framing of a natural and yet cultural sphere came with many fierce debates on whose Wadden Sea it actually was and who would have the right of interpretation. The economic demand for new agricultural land and embankment schemes ceased. Instead, tourism turned into an ever-growing source of income along the coast. It caused problems but also opened up new channels for stirring public awareness and constituencies. The dikes minimised the constant threat posed by an unpredictable sea. The North Sea was no longer a source of potential human catastrophe but became the potential victim of environmental catastrophes caused by humans. Travelling pollutants threatened not only maritime species but also human health. Environmental problems grew in size and outreach. Moreover, the late 1960 s and early 1970 s saw the formation of environmental internationalism. The global environmental crisis emphasised the necessity of protecting maritime 
ecosystems. In addition, the accelerating process of Europeanisation forced member states to think in new terms and along alternative geographies that went beyond the nation-state. Nature entered the arena of diplomacy. Urban environmentalists joined forces with old school conservationists. Civil society and ecology formed influential alliances. Visual and medial representations of the Wadden sphere changed over time. The peculiar coastal area was constructed as a transnational object of protection within a conceptual and legal framework developed by transnational organisations. All this paved the way for a broader political acceptance of a coherent concept of the Wadden Sea based on tits framing as an ecological entity. The environmental history approach, however, demonstrates that perceptions of nature are in constant flow and might quickly change again.

\section{References}

Bietz, H. (2004). Die Entwicklung der deutschen Wattenmeerforschung: Ein wissenschaftlicher Beitrag zur Bedeutung der Pionierarbeiten. Bremerhaven: Alfred Wegener-Institut.

Blackbourn, D. (2007). Die Eroberung der Natur. Eine Geschichte der deutschen Landschaft. Munich: Beck.

Blackbourn, D. (2011). Environmental History and Other Histories. In Coulter, K. and Mauch, C. (eds.), The Future of Environmental History. Needs and Opportunities, RCC Perspectives 3/2022, 19-21. Munich: Rachel Carson Center.

Deen, M. (2014). De Wadden. Een Geschiedenis. Amsterdam: Thomas Rap.

Enemark, J. (2005). The Wadden Sea protection and management scheme - towards an integrated coastal management approach? Ocean \& Coastal Management 48, 996-1015.

Erz, W. (1972). Nationalpark Wattenmeer. Hamburg and Berlin: Parey.

European Commission (1995). Wise use and conservation of wetlands. COM (95) 189. Brussels: European Commission.

Freriks, K. (2015). De kleuren van het wad. Van bedreigde zee tot werelderfgoed. Assen: Koninklijke Van Gorcum.

Gillis, J.R. (2011). Filling the Blue Hole in Environmental History. In Coulter, K. and Mauch, C. (eds.), The Future of Environmental History. Needs and Opportunities, RCC Perspectives 3/2022, 16-18. Munich: Rachel Carson Center.

IUCN (1965). Liquid assets. Morges: International Union for Conservation of Nature. Koeman, J.H., Veen, J., Brouwer, E., Huisman-de Brouwer, L. and Koolen, J.L. (1968). Residues of chlorinated hydrocarbon insecticides in the North Sea environment. Helgoländer wissenschaftliche Meeresuntersuchungen (17), 375-380. 
Kohl, J. (1846). Die Marschen und Inseln der Herzogthümer Schleswig und Holstein. Dresden \& Leipzig: Arnoldische Buchhandlung.

Landelijke Vereniging tot Behoud van de Waddenzee/Vereniging tot Behoud van Natuurmonumenten in Nederland (eds.) (1976). Wattenmeer. Neumünster: Wachholtz.

Lausche, B. J. (2008). Weaving a Web of Environmental Law. Berlin: Schmidt.

Lotze, H., Reise, K. and Worm, B. (2005). Human Transformations of the Wadden Sea Ecosystem through Time: a Synthesis. Helgoland Marine Research (59), 84-95. Matthews, G. (1993). The Ramsar Convention on Wetlands: its History and Development. Gland: Ramsar Bureau.

Möbius, K. (1877). Die Auster und die Austernwirthschaft. Berlin:Wiegandt, Hempel \& Parey.

Radkau, J. (2011). Die Ära der Ökologie. Eine Weltgeschichte. Munich: Beck.

Reise, K. (2013). A Natural History of the Wadden Sea. Riddled by Contingencies. Wilhelmshaven: Waddenacademie \& Common Wadden Sea Secretariat.

Scott, P. (1963). Introductory Remarks. In IUCN: Project MAR. The conservation and management of temperate Marshes, bogs and otherwetlands. Proceedings of the MAR conference organized by IUCN, ICPB and IWRB (32-34). IUCN Publications news series No. 3. Morges: IUCN.

Umweltbundesamt (2002). Gesamtsynthese Ökosystemforschung Wattenmeer. Erfahrungsbericht eines interdisziplinären Verbundvorhabens. Berlin: UBA.

Van der Windt, H. (1992). Environmental Scientists and Scientific Symposia in the Wadden Sea Area, a Changing Role. In Dankers, N., Smit, C.J. and Scholl, M. (eds.), Proceedings of the 7 th International Wadden Sea Symposium (pp. 117-127). Texel: Netherlands Institute for Sea Research.

Weigold, H. (1924). Die Vogelfreistätten der deutschen Nordsee. Meereskunde 159 (14), 375-84.

Westerman, F. (2009). Das Getreideparadies. Berlin: Ch. Links Verlag.

Wöbse, A.K. (2015). Über Grenzen hinweg. Zur internationalen Geschichte der ehrenamtlichen Zusammenarbeit im Wattenmeerschutz. In Nationalparkverwaltung LKN.SH, Tönning (eds.), Mit uns für das Watt! Ehrenamtliche und der Schutz des Wattenmeers, 12-22). Tönning: Nationalparkverwaltung LKN.SH.

Wöbse, A. K. (2016). Die ausgezeichnete Natur Europas Zur Geschichte eines Labels. Retrieved February 01, 2018, from http://www.europa.clio-online.de/essay/id/ artikel-3803.

Wöbse, A.K. (2017). Space, Place, Land and Sea: The Ecological 'Discovery' of the Global Wadden Sea. In De Bont, R. and Lachmund, J. (eds.), Spatializing the History of Ecology. Sites, Journeys, Mappings, 204-222. London \& New York: Routledge. 
Wolff-de Boom, I. (1983). International conventions relevant for the protection and the management of the Wadden Sea area. In Mörzer Bruyns, M. and Wolff, W.J. (eds.), Nature conservation, nature management and physical planning in the Wadden Sea area, 145-152. Leiden: Stichting Veth tot Steun aan Waddenonderzoek.

Wolff, W.J. (ed.) (1976). Proceedings of the Conference of Wadden Sea Experts held at the Island of Schiermonnikoog. The Hague: Netherlands Government Pr. Office. Wolff, W.J. (ed.) (1983). Ecology of the Wadden Sea. Rotterdam: Balkema.

Wolff, W.J. (1997). Development of the Conservation of Dutch Coastal Waters. Aquatic Conservation: Marine and Freshwater Ecosystems, 7, 165-77.

Wolff, W.J. (2013). Ecology of the Wadden Sea: Research in the past and challenges for the future. Journal of Sea Research, 82, 3-9.

Ziemek, H.P. and Wöbse, A.K. (2016). Nationalpark Schleswig-Holsteinisches Wattenmeer. In: Frohn, H.W. Küster, H. and H.P. Ziemek (eds.), Ausweisungen von Nationalparks in Deutschland - Akzeptanz und Widerstand, 67-106. Bonn, Bad Godesberg: Bundesamt für Naturschutz.

\section{About the authors}

Dr. Anna-Katharina Wöbse is an environmental historian and research associate at the University of Gießen. She has published extensively on animal-human relations, visual history, the history of transnational environmental movements, and the environmental diplomacy in the League of Nations and the UN. Currently, she is involved in a multidisciplinary research project exploring the transnational history of European wetlands.

Prof. Hans-Peter Ziemek is professor of biological didactics at the University of Gießen. He has conducted extensive research on science and nature education, public relations in conservation, and the history of science. His current research interest lies in the history of national parks and the World Heritage Site of the Wadden Sea. 
